Nurcan Kızılcık,

Erhan Çelikoğlu,

Taha Keleştemur,

Özge Köner,

Merih İş,

Sevgi Bilgen,

Ayçiçek Çeçen,

Bayram Yılmaz

\section{Comparing Effects of Intraventricular Hypertonic Saline and Magnesium Sulfate Application on Diffuse Brain Injury in Rats}

\author{
Ratlardaki Diffüz Beyin Travmasında Hipertonik Salin \\ ve Magnezyum Sülfatın Intraventriküler Uygulamayla \\ Etkilerinin Karşılaştıııması
}

Received/Geliș Tarihi : 10.09.2016

Accepted/Kabul Tarihi : 16.02.2017

${ }^{\circ}$ Copyright 2017 by Turkish Society of Intensive Care Journal of the Turkish Society of Intensive Care published by Galenos Publishing House.

Nurcan Kızılcık, Taha Keleştemur, Özge Köner, Sevgi Bilgen, Bayram Yılmaz

Yeditepe University Faculty of Medicine, Department of Anesthesiology, Istanbul, Turkey

Erhan Çelikoğlu, Merih Iş, Ayçiçek Çeçen

Fatih Sultan Mehmet Training and Research Hospital, Clinic of Neurosurgery, Istanbul, Turkey

Nurcan Kızılcık (困),

Yeditepe University Faculty of Medicine, Department of Anesthesiology, Istanbul, Turkey

E-mail :nurcankizilcik@yahoo.com

Phone : +90 5327765444
ABSTRACT Objective: Diffuse brain injury is one of the most common issues encountered in, patients with trauma and it leads to morbidity and mortality via increased intracranial pressure. The aim of the study was to compare the effects of magnesium sulfate and hypertonic saline on diffuse brain injury in rats.

Materials and Methods: In this study 18 male Sprague-Dawley rats weighing 250-300 g were used. The rats were randomly divided into trauma (control), trauma+magnesium, and trauma+hypertonic saline groups. Traumatic brain injury was induced by modified Feeney head trauma model. A single dose of $10 \mu \mathrm{L}$ isotonic saline, magnesium sulphate and hypertonic saline were applied intraventricularly to the control, magnesium, and hypertonic saline groups, respectively. Rats were decapitated 24 hours after the head trauma. Their brains were dissected immediately and stored with dry ice at $-80^{\circ} \mathrm{C}$ for histopathological experiments.

Results: The number of damaged neurons were significantly higher in both control and hypertonic saline groups $(p=0.001, p=0.008$ ). However, the number of damaged neurons did not show significant difference between hypertonic saline and control groups, it was significantly lower in magnesium group $(p<0.05)$.

Conclusion: In this study, intraventricular magnesium application is found effective in reducing the number of the damaged neurons in rat traumatic brain injury model. These results suggest that magnesium usage may be evaluated for the treatment of patients with traumatic brain injury in further prospective studies.

Keywords: Traumatic brain injury, hypertonic saline, magnesium sulfate

ÖZ Amaç: Diffüz beyin hasarı travmada en yaygın karşılaşılan sorunlardan biridir ve artmış kafa içi basıncı vasıtasıyla morbidite ve mortalite yol açar. Çalışmamızın amacı, sıçanlarda magnezyum sülfat ve hipertonik salinin diffüz beyin hasarı üzerine etkisini karşılaştırmaktır.

Gereç ve Yöntem: Çalışmamızda 250-300 gr ağırlığında 18 erkek Sprague-Dawley sıçan kullanıldı. Sıçanlar randomize olarak travma (kontrol), travma+magnezyum ve travma+hipertonik salin olmak üzere üç gruba ayrıldı. Travmatik beyin hasarı modifiye Feeney kafa travması modeli ile oluşturuldu. Sırasıyla gruplara 10 mcL izotonik, magnezyum sülfat ve hipertonik salin tek doz, intraventriküler uygulanmıştır. Sıçanlar travmadan 24 saat sonra dekapite edildi. Beyinleri hemen diseke edildi ve histopatolojik deneyler için $-80{ }^{\circ} \mathrm{C}$ kuru buz ile saklandı.

Bulgular: Hasarlı nöron sayısı hem kontrol hem de hipertonik salin grubunda anlamlı olarak yüksekti $(p=0,001, p=0,008)$. Ancak, hipertonik salin ve kontrol grupları arasında anlamlı bir fark yoktu, magnezyum grubunda anlamlı olarak daha düşüktü $(p<0,05)$.

Sonuç: Intraventriküler magnezyum uygulaması bu çalışmada sıçanlardaki travmatik beyin hasarı modelinde, hasarlı nöronların sayısını azaltmada etkili bulunmuştur. Bu sonuçlar ileri prospektif çalışmalarda travmatik beyin hasarı olan hastaların tedavisinde magnezyum kullanımının değerlendirilebileceğini düşündürmektedir.

Anahtar Kelimeler: Travmatik beyin hasarı, hipertonik salin, magnezyum sülfat 


\section{Introduction}

Formation of the brain edema is one of the most challenging problems encountered after the head trauma $(1,2)$. It leads to morbidity and mortality via increased intracranial pressure, for which many efforts have been made for the best treatment for the several years $(2,3)$.

Mannitol is the most popular pharmacological treatment hyperosmotic agent used in post-traumatic brain damage (4). It has been suggested that mannitol, by creating an osmotic gradient between the brain tissue and plasma, leads the edema fluid to flow into vascular bed (5). In addition, by producing hemodilution and red cell deformity, mannitol increases blood flow to the tissues and reduces cerebrospinal fluid release from the choroids plexus $(6,7)$. Another effective methods for decreasing neural damage due to the increased intracranial pressure is the external ventricular drainage by the insertion of a catheter directly into the lateral ventricles (8). Barbiturates and hyperventilation may also be used for a limited period of time, and use of steroids as a membrane stabilizer is still under investigation $(9,10)$.

In spite of all the treatment modalities mentioned above, treatment of traumatic brain injury (TBI) remains as a challenging problem. In recent years, there have been tendencies to use hypertonic saline for treatment of brain edema and neuronal damage due to its safety advantages over mannitol $(10,11)$. However, the most appropriate osmotherapeutic agent is still need to be determined.

Magnesium sulfate is a noncompetitive inhibitor of the $\mathrm{N}$-methyl-D aspartic acid (NMDA) receptors and ion channels in the brain, providing protective effect on blood brain barrier in experimental models (12). It has been reported that magnesium improves functional outcome following blood brain barrier disruption and decrease brain edema (13). Studies on the effect of magnesium or hypertonic saline in experimental models commonly applied intraperitoneal or intra-arterial way of drug administration $(13,14)$. However, the efficacy of intraventricular hypertonic saline and magnesium on brain cell damage in severe head injury has not been evaluated yet. In the present study, we compared the direct intraventricular effects of hypertonic saline a well-known osmotic agent decreasing intracranial pressure and magnesium sulphate an NMDA receptor inhibitor that has recently-shown to have neuroprotective effects on injured neuron cells after brain trauma in rats.

\section{Materials and Methods}

\section{Study Design and Animals}

This was an experimental study in which 18 male Sprague-Dawley rats weighing 250-300 gr were used. The rats were housed in standard plastic cages on sawdust bedding in an air-conditioned room at $22 \pm 1^{\circ} \mathrm{C}$. Standard rat food and tap water were given ad libitum before and after the experiment. Eighteen rats were divided into three groups each containing six rats: control group (C), trauma+magnesium (TM) group, and trauma+hypertonic (TH) saline group.

The animal experiments and procedures were performed in accordance with national guidelines for the use and care of laboratory animals. The study protocol was approved by Yeditepe University Animal Care and Use Committee (13.04.2012/263).

\section{Experimental Traumatic Brain Injury Model}

The blunt head trauma model of Feeney were modified and used to induce brain injury in rats. Following anesthesia with xylazine $(10 \mathrm{mg} / \mathrm{kg}$, Rompun $2 \%$, Bayer, Istanbul, Turkey) and ketamine $(100 \mathrm{mg} / \mathrm{kg}$, Ketalar, Parke Davis/Eczacıbaşı, Istanbul, Turkey), rats were placed in a stereotaxic frame (Stoelting Co-Stellar Cat No.51400, USA) bregma was marked as the reference point. Approximately $1 \mathrm{~cm}$ incision was made on the sagittal plane reaching the skull by using a dentist burr, centering $2.5 \mathrm{~mm}$ laterally on the right and $2.5 \mathrm{~mm}$ posteriorly. A circular bone flap of $6 \mathrm{~mm}$ diameter was excised. After replacement of metallic piece at the same diameter, a 10 $\mathrm{g}$ weight was dropped by free falling from a glass tube with inner diameter $8 \mathrm{~mm}$ at $50 \mathrm{~cm}$ height targeting the piece placed on the brain. Five minutes after the trauma, a single dose $(10 \mu \mathrm{L})$ of isotonic saline $(0.9 \% \mathrm{NaCl})$, magnesium sulphate, and hypertonic saline $(23.4 \%$ $\mathrm{NaCl}$ ) was applied intraventricularly into the control, magnesium, and hypertonic saline groups, respectively. After this procedure, skin was covered by interrupted sutures, and rats were put on homeothermic blanket system until awake and replaced in their cage. All of the rats decapitated at the $24^{\text {th }}$ hour after the procedure.

Blood samples were taken from the femoral artery before cerebral injury procedure and after 24 hours to determine sodium, potassium, chloride, calcium, magnesium, and hematocrit levels.

\section{Histopathological Evaluation}

Hippocampus and cortex were dissected for histopathologic evaluation. Nine of $5 \mu \mathrm{m}$ thin sections of the brain were stained with cresyl violet and indocyanine green. Sections were processed for the TUNNEL assay using InSitu Cell-Death Detection (POD) kits, (Roche, Penzberg, Germany) to reveal the degree of apoptosis under each experimental condition. The number of the injured neurons were counted (Figure 1). 


\section{Statistical Analysis}

Study data were summarized by descriptive statistics (e.g., mean, standard deviation, frequency, percentage). The normality distribution of data was tested by KolmogorovSmirnov test. One-way analysis of variance (ANOVA) and post-hoc Tukey test were used to analyze the quantitative data that show normal distribution. In order to compare data without normal distribution, Kruskal-Wallis and MannWhitney $U$ tests were used. Paired sample t-test was applied for repeated measurements. Statistical analysis was performed using the SPSS software package for Windows (Statistical Package for Social Sciences, version 15.0, SPSS Inc., Chicago, IL, USA). Statistical level of significance was set to $p<0.05$.
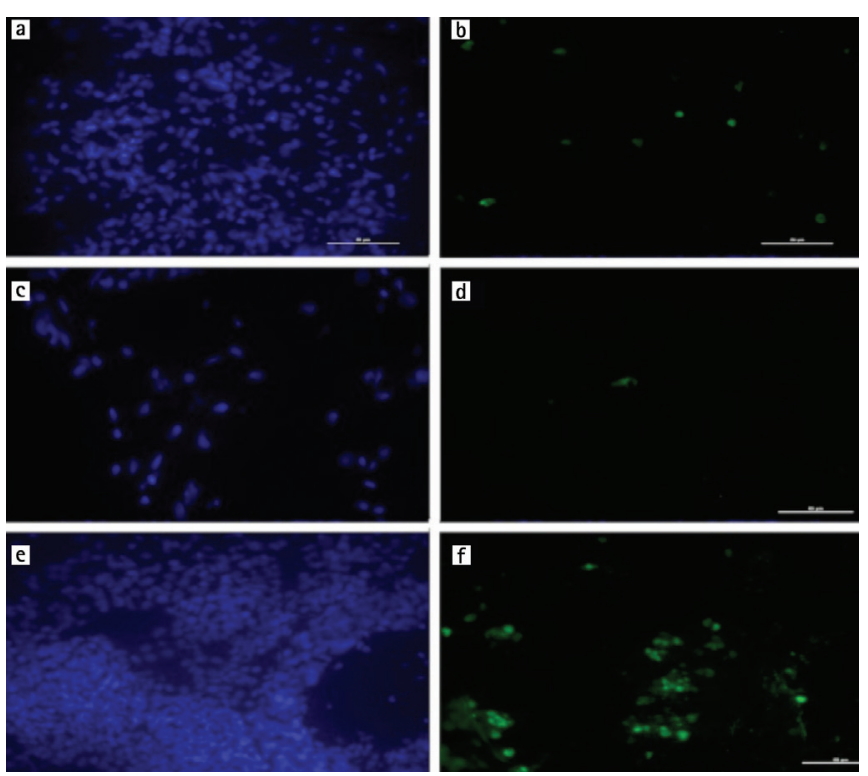

Figure 1. Microscopic images of the stained brain tissue of hypertonic saline $(a, b)$, magnesium $(c, d)$, and control groups $(e, f)$. Images on left were stained with cresyl violet, and images on right indocyanine green.

\section{Results}

\section{Number of Injured Neurons}

The mean number of injured neurons ranged between 76 and 199 in brain tissue sections stained with cresyl violet and between 13 and 23 in tissues stained with indocyanine green. The number of injured neurons calculated from each of nine thin sections of the brain stained with cresyl violet and indocyanine green are shown in Table 1. The number of injured neurons was significantly lowest in magnesium group compared to control and hypertonic saline groups at six sections stained with cresyl violet and at seven sections stained with indocyanine green ( $p<0.05$ for all, Table 1$)$ without any significant difference between control and hypertonic saline groups ( $p>0.05$ ). This shows that although magnesium significantly decreases the number of injured neurons by brain injury, hypertonic saline had no effect on injured neurons.

\section{Blood Analysis}

Blood levels of sodium, potassium, chloride, calcium, magnesium, and hematocrit levels showed no statistically significant difference between control, hypertonic saline and magnesium group before and 24 hours after the injury ( $p>0.05$ for all). Sodium level, however, increased significantly after the injury in all groups ( $p<0.05$ for all). Chloride also increased 24 hours after the injury compared to levels before the injury, but this increase reached statistical level of significance only in hypertonic saline group $(p=0.019)$.

\section{Discussion}

TBI is a common emergency problem associated with high morbidity and mortality rates in intensive care unit. In the present study, we compared the direct intraventricular

\begin{tabular}{|c|c|c|c|c|c|c|c|c|}
\hline Sections & M:C (CV) & M:C (IG) & M:TM (CV) & M:TM (IG) & M:TH (CV) & M:TH (IG) & $p(C V)$ & $p(I G)$ \\
\hline 1 & 145 & 15 & 90 & 9.6 & 100 & $4^{*}$ & 0.3 & 0.001 * \\
\hline 2 & 132 & 14 & 97 & 13.5 & 101 & $5.5^{*}$ & 0.1 & $0.07^{*}$ \\
\hline 3 & $187^{*}$ & 16 & 77 & 24 & 80 & $8^{*}$ & $0.01 *$ & $0.04^{*}$ \\
\hline 4 & 77 & 15 & 63 & 26 & $203^{*}$ & $3.5^{*}$ & $0.004^{*}$ & $0.01 *$ \\
\hline 5 & 103 & 23.5 & 79 & 12.6 & 125 & $3^{*}$ & 0.1 & $0.001^{*}$ \\
\hline 6 & 126 & 15 & $50^{*}$ & 13 & 119 & $5.8^{*}$ & $0.01 *$ & 0.1 \\
\hline 7 & $196^{*}$ & 13.5 & 75 & 20 & 105 & $3^{*}$ & $0.001 *$ & $0.002 *$ \\
\hline 8 & $199^{*}$ & 21 & 63 & 18 & 80 & $3.8^{*}$ & $0.004^{*}$ & $0.005^{*}$ \\
\hline 9 & 192 & 24 & $72^{*}$ & 18 & 159 & $1.8^{*}$ & $0.01 *$ & 0.006 * \\
\hline
\end{tabular}


effects of hypertonic saline a well-known osmotic agent decreasing intracranial pressure and magnesium sulphate an NMDA receptor inhibitor that has recently-shown to have neuroprotective effects on injured neuron cells after brain trauma in rats. We have found that magnesium sulphate effectively decreased the number of injured neurons, whereas hypertonic saline had no direct effect on injured neurons in rats after TBI.

In cases of TBI, post-traumatic brain edema increases intracranial pressure, which may lead to death as well as disastrous complications. The post-traumatic brain edema may be divided into two groups according to its mechanism of formation: vasogenic and cytotoxic edema (2,15). Evidence from some studies using different models of head injury indicated that the bloodbrain barrier leakage reaches a peak level within 30 min following trauma $(2,10)$. This early and short term of edema is followed by a late edema that begins a few hours, and has a maximum effect between 3 and 8 days after trauma $(2,9,10,16)$. It now becomes clear from the current literature that head injury is associated with biphasic pathophysiologic response, namely the first and short duration of vasogenic, and the second, the prolonged cytotoxic edema $(1,2,10)$.

The TBI is managed by a multidisciplinary team usually with the aim of decreasing edema, maintenance of cerebral perfusion pressure and cerebral oxygenation (16). Hyperosmolar therapy using mannitol or hyperosmolar saline is a key intervention to overcome cerebral edema. Due to potential complications of mannitol such as intravascular volume depletion, hypotension, and hyperkalemia, hypertonic saline has been increasingly used as a safer alternative to mannitol $(11,17,18)$. However, even though it has safety advantages over mannitol, there is a still controversy on the optimal dose or concentration of hypertonic saline. Furthermore, the effect of hyperosmolar agents is temporary and associated with sudden changes in serum sodium concentration and osmolarity (16). Therefore, alternative agents to decrease cerebral edema and intracerebral pressure permanently are needed in clinical practice.

$\mathrm{N}$-methyl-D aspartic acid antagonists have been shown to be neuroprotective in animal models of brain injury and ischemia (19). Intracellular magnesium concentrations have been shown to decrease after TBI and this decline is attenuated by non-competitive NMDA receptor antagonists, with a corresponding improvement in neurological outcome. Browne et al. (20) demonstrated long-term neuroprotection of hippocampal tissue by an acute treatment with magnesium sulphate in a rat brain trauma model.
Imer et al. (14) reported that magnesium, alone or in combination with MK-801 reduces brain edema and restores permeability of blood brain barrier after experimental diffuse brain injury. Kaya et al. (21) also found that intraperitoneal magnesium sulfate administration limits the transient osmotic opening of the blood brain barrier. In another study from the same team, intraperitoneal magnesium was found to attenuate the blood-brain barrier permeability defect, which occurs in a rat model of diffuse TBI or in rat model and intraperitoneal sepsis $(13,22)$.

In the present study, unlike previous studies that commonly used intraperitoneal rout, we gave magnesium sulphate and hypertonic saline via intraventricular route in order to demonstrate the direct action of these agents on injured neurons. We found that magnesium sulphate decreased the number of injured neurons, whereas hypertonic saline did not. Blood levels of electrolytes did not change after the injury except sodium level, which increased in all groups, and chloride level, which increased only in hypertonic saline group. It is known that hypertonic saline reduces cerebral edema and intracranial pressure $(11,16,18)$. On the other hand, it has no known direct effect on injured neurons by brain trauma. Therefore, it is not surprising that in the present study, where only the number of neurons but not intracranial pressure was evaluated, hypertonic saline seems ineffective for TBI. However, magnesium plays an important role in the conduction of the nervous system via a voltage-gated antagonist action at the NMDA receptor. Therefore it has neuroprotective effect as shown in previous studies $(19,20)$. Our findings confirm neuroprotective effect of magnesium sulphate in TBI model by decreasing the number of the injured cells while hypertonic saline had no direct effect on injured neural tissue.

The main limitations of the present study were the small sample size per study group, the use rat brain trauma model, which does not reflect the complexity of clinical head injury and limited applicability of the doses and concentration of therapeutic agents used in rats to human subjects (23). Thus, our findings should be confirmed by large-scale clinical studies with various doses and application routes of magnesium sulphate and hypertonic saline.

In conclusion, intraventricular magnesium, but not hypertonic saline, is effective in reduction of injured neuron count in rat TBI model. On this basis, further clinical prospective studies are needed to evaluate the use of magnesium in the management of patients with TBI.

\section{Ethics}

Ethics Committee Approval: Yeditepe University Animal Care and Use Committee. Informed Consent: 
Yeditepe University Animal Care and Use Committee (13.04.2012/263).

Peer-review: External and Internal peer-reviewed.

Authorship Contributions

Surgical and Medical Practices: T.K., N.K., M.I., B.Y., Concept: N. K., M.I., Design: N.K., M.I., Data Collection or
Processing: N.K., M.I., Ö.K., S.B., Analysis or Interpretation: N.K., Literature Search: N.K., E.Ç., A.Ç., Writing: N.K., M.I. Conflict of Interest: No conflict of interest was declared by the authors.

Financial Disclosure: The authors declared that this study received no financial support.

\section{References}

1. Unterberg AW, Stover J, Kress B, Kiening KL. Edema and brain trauma. Neuroscience 2004;129:1021-9.

2. Alluri H, Wiggins-Dohlvik K, Davis ML, Huang JH, Tharakan B. Bloodbrain barrier dysfunction following traumatic brain injury. Metab Brain Dis 2015;30:1093-104

3. Fink ME. Osmotherapy for intracranial hypertension: mannitol versus hypertonic saline. Continuum (Minneap Minn) 2012;18:640-54.

4. Wakai A, McCabe A, Roberts I, Sechierhout G. Mannitol for acute traumatic brain injury. Cochrane Database Syst Rev 2013:CD001049.

5. Davis M, Lucatorto M. Mannitol revisited. J Neurosci Nurs 1994:26:170-4.

6. Mendelow AD, Teasdale GM, Russell T, Flood J, Patterson J, Murray GD. Effect of mannitol on cerebral blood flow and cerebral perfusion pressure in human head injury. J Neurosurg 1985;63:43-8.

7. Diringer MN, Scalfani MT, Zazulia AR, Videen TO, Dhar R. Cerebral hemodynamic and metabolic effects of equi-osmolar doses mannitol and $23.4 \%$ saline in patients with edema following large ischemic stroke. Neurocrit Care 2011;14:11-7.

8. Dey M, Jaffe J, Stadnik A, Avad IA. External ventricular drainage for intraventricular hemorrhage. Curr Neurol Neurosci Rep 2012;12:24-33.
9. Madikians A, Giza CC. Treatment of traumatic brain injury in pediatrics. Curr Treat Options Neurol 2009;11:393-404.

10. Williams $\mathrm{OH}$, Tallantyre EC, Robertson NP. Traumatic brain injury: pathophysiology, clinical outcome and treatment. J Neurol 2015;262:1394-6

11. Lazaridis $C$, Neyens $R$, Bodle J, DeSantis SM. High-osmolarity saline in neurocritical care: systematic review and meta-analysis. Crit Care Med 2013;41:1353-60.

12. Heath DL, Vink R. Neuroprotective effects of $\mathrm{MgSO} 4$ and $\mathrm{MgC} 12$ in closed head injury: a comparitive phosphorus NMR study. J Neurotrauma 1998;15:183-9.

13. Esen F, Erdem T, Aktan D, Orhan M, Kaya $\mathrm{M}$, Eraksoy $\mathrm{H}$, et al. Effect of magnesium sulfate administration on blood-brain barrier in a rat model of intraperitoneal sepsis: a randomized controlled experimental study. Crit Care 2005;9:1823.

14. Imer M, Omay B, Uzunkol A, Erdem T, Sabancı PA, Karasu A, et al. Effect of magnesium, MK-801 and combination of magnesium and MK-801 on blood-brain barrier permeability and brain edema after experimental traumatic diffuse brain injury. Neurol Res 2009;31:977-81.

15. Donkin JJ, Vink R. Mechanisms of cerebral edema in traumatic brain injury: therapeutic developments. Curr Opin Neurol 2010;23:293-9.

16. Helmy A, Vizcaychipi M, Gupta AK. Traumatic brain injury: intensive care management. Br J Anaesth 2007;99:3242.

17. Manninen $\mathrm{PH}$, Lam AM, Gelb AW, Brown SC. The effect of high-dose mannitol on serum and urine electrolytes and osmolality in neurosurgical patients. Can J Anaesth 1987;34:442-6.

18. Zornow $\mathrm{MH}$. Hypertonic saline as a safe and efficacious treatment of intracranial hypertension. J Neurosurg Anesthesiol 1996:8:175-7.

19. Wang CX, Shuaib A. NMDA/NR2B selective antagonists in the treatment of ischemic brain injury. Curr Drug Targets CNS Neurol Disord 2005;4:143-51.

20. Browne KD, Leoni MJ, Iwata A, Chen XH, Smith $\mathrm{DH}$. Acute treatment with $\mathrm{MgSO} 4$ attenuates long-term hippocampal tissue loss after brain trauma in the rat. $J$ Neurosci Res 2004;77:878-83.

21. Kaya M, Gulturk S, Elmas I, Kalaycı R, Arican N, Koçyildiz ZC, et al. The effects of magnesium sulfate on blood-brain barrier disruption caused by intracarotid injection of hyperosmolar mannitol in rats. Life Sci 2004;76:201-12.

22. Esen F, Erdem T, Aktan D, Kalayci R, Cakar $N$, Kaya $M$, et al. Effects of magnesium administration on brain edema and blood-brain barrier breakdown after experimental traumatic brain injury in rats. J Neurosurg Anesthesiol 2003;15:119-25.

23. Cernak I. Animal models of head trauma NeuroRx 2005:2:410-22 